\title{
BIOLOGICAL ACTIVITY OF ESSENTIAL OIL OF PITANGA (Eugenia uniflora L.) LEAVES
}

FERNANDA SVIECH ${ }^{1}$

KARLOS E. PIANOSKI

ROBERTA L. KRUGER ${ }^{3}$

VALESCAKOTOVICZ ${ }^{4}$

EDUARDA M. BAINY ${ }^{5}$

GUILHERME S. B. SAKATA ${ }^{6}$

MICHELE C. M. BOMBARDELLI ${ }^{7}$

\begin{abstract}
Many natural extracts present antioxidant and antimicrobial propertiesthatcan replace synthetic additives. This study aimed to extract essential oil from Pitanga (Eugenia uniflora L.) leaves and to evaluate its chemical composition, antioxidant and antibacterial activities. The essential oil was obtained by hydrodistillation with a yield of $1.34 \pm 0.18 \%$. The total antioxidant activity was evaluated by the DPPH and phosphomolybdenum methods. The oil presented an $\mathrm{IC}_{50}$ value of $100.96 \mu \mathrm{L} \mathrm{mL}^{-1}$ and $1503.44 \pm 29.48 \mathrm{mg}^{\alpha}$-tocopherol mL $\mathrm{m}^{-1}$ of oil. The major compounds identified by the GC-MS were germacrone (13.57\%), spathulenol (7.49\%), curzerene (5.31\%) and $\alpha-$ cadinol $(4.70 \%)$. The oil was also evaluated for its antimicrobial activity and was effective against Staphylococcus aureus. These results show that essential oil of pitanga leaves have good antioxidant and antimicrobial activity, being an alternative source of bioactive compounds.
\end{abstract}

1 Food engineering undergraduate student, Department of Food Engineering, State University of Midwest, Guarapuava, PR, Brazil (email: fer sviech@hotmail.com)

2 Chemist, Master's in Chemistry, Department of Chemistry, State University of Midwest, CEP 85040-080, Guarapuava, PR, Brazil (email: karlosdrd@gmail.com)

3 Professor, Department of Food Engineering, State University of Midwest, Guarapuava, PR, Brazil (email: betakruger@yahoo.com.br)

4 Professor, Department of Food Engineering, State University of Midwest, Guarapuava, PR, Brazil (email: valescakotovicz@yahoo.com.br)

5 Professor, Food Science and Technology Graduate Program, Federal University of FronteiraSul, Laranjeiras do Sul, PR, Brazil (email: eduarda.bainy@uffs.edu.br)

6 Food engineering undergraduate student, Department of Food Engineering, State University of Midwest, Guarapuava, PR, Brazil (email: guisakata@gmail.com)

7 Professor, Department of Food Engineering, State University of Midwest, Guarapuava, PR, Brazil (email:mimesomo@yahoo.com.br). Corresponding author. 


\section{INTRODUCTION}

The growing interest for natural foods and evidence that some synthetic additives may promote health side effects, such as allergies, hyperactivity (Polônio and Peres, 2009) and cancer (Botterwercket al., 2000) have increased the demand for natural compounds with similar activities.In this context, natural extracts have been studied as alternative food preservatives in the food industry due to their potential to act as antioxidant (Misharinaet al., 2009) and antimicrobial (Pisoschiet al., 2018) agents.In addition, they have been widely applied in perfumery, cosmetic, pharmaceutical and textiles industries (Cavalcanti et al., 2013). Natural extracts also provide beneficial human health effects (Ibañezet al., 2003).

Plant extracts are products with high added-value and are composed of a complex mixture of numerous substances which are thermal degradable. The extraction methods considerably influence their quality (Alexandre et al., 2017). The extraction of bioactive compounds from plants has been carried out by various methods, including alcoholics (Chan et al., 2007), aqueous (Sivasothyet al., 2011), hydrodistillation(Mesomo et al., 2013) and supercritical fluids (Mesomo et al., 2012).

Essential oils are obtained by the hydrodistillation method. The antioxidant and antimicrobial properties of these essential oils are determined by their composition. Among the phytochemicals capable of acting as antioxidants are minerals (zinc and selenium), vitamins (A, C, E and K), carotenoids and phenolic compounds (Nahaket al., 2014).Many plant materials contain phenolic compounds and a significative quantity is available for human consumption (Kähkönenet al.,1999).

Phenolic compounds include several groups of organic substances and the major classes are phenolic acidsand flavonoids(Soares, 2002). They act as antioxidants by scavenging free radicals such as peroxide, hydroperoxide or lipid peroxyl, and thus preventing the oxidative reactions (Nahaket al., 2014).Flavonoids are also iron chelatorswhich improve the inhibition of lipid peroxidation (Van Acker et al., 1996).

Essential oils with high levels of substituted phenols can reduce the oxidation processes of unsaturated aldehydes, even at low concentrations (Misharinaet al.,2009). In addition, plant-derived antimicrobials can inactivate microorganisms and enzymes without affecting the nutritional and sensory properties of food (Pisoschiet al., 2018). The major components responsible for the antimicrobial properties of plants EOs are phenolics (flavonoids and non-flavonoids), terpenes, aliphatic alcohols, aldehydes, among others (Pisoschiet al., 2018).

Fruits and vegetables are known sources of antioxidant and antimicrobial compounds. Eugenia unifloraL., popularly known as Pitanga, Surinam cherry or Brazilian cherry, belongs to the Myrtaceae family and it is native to Brazil and Argentina (Franzonet al., 2018). Its leaves are used in popular medicine as a tea and have application for the treatment of hypertension, gout, stomach disorders, rheumatism and yellow fever (Denardinet al., 2015). It also has edible fruits which are widely appreciated in Brazil.

The essential oil obtained from Pitanga leaves is used by the cosmetics industry; however, its commercial application is still limited (Franzonet al., 2018). Victoria et al. (2013) showed that it has antidepressant and antioxidant properties. The authors suggested that it can be used for the development of phytomedicines due to the modulation of serotoninergic and adrenergic systems. Additionally, the biological activities of $E$. uniflora as antihypertensive, anti- 
rheumatic, antifungal, diuretic, among others, have been reported in the literature (Bezerraet al., 2018).

Ethanolic extract of Eugenia uniflora L. leaves characterized by HPLC showed that quercetin and quercitrin were the major components, while chlorogenic acid and gallic acid were the least abundant (Cunha et al., 2016). The presence of polyphenolic compounds, such as quercetin, quercitrin, isoquercitrin, luteolin and ellagic acid, may be responsible for its beneficial effects as cytotoxic and antioxidative (Cunha et al., 2016). These studies evidence the relevance of this material for pharmacological (Bezerraet al., 2018) and food applications.Consequently, it is important to conduct more studies to identify alternative sources of extracts with high contents of bioactive compounds, such as Pitanga leaves.

The main objectives of this study were to evaluate the chemical composition, antioxidant activity and antibacterial activity of essential oil of Pitanga (Eugenia unifloraL.) leaves obtained by the hydrodistillation process.

\section{MATERIAL AND METHODS}

\subsection{SAMPLE PREPARATION}

The pitanga (Eugenia unifloraL.) leaves were collected in the region of Palmeira (State of Paraná, Brazil). They were dried in an air circulation oven at $303.15 \mathrm{~K} \pm 2 \mathrm{~K}$ until reaching a moisture content of $10.28 \pm 1.05 \%$. The dried leaves were ground in a food processor and stored in a freezer $(255.15 \mathrm{~K} \pm 2 \mathrm{~K})$ until extraction. The moisture content $(\mathrm{H})$ of the raw material and the dried samples were measured by the toluene distillation method according to AOCS (1994), which can distinguish water from the volatile material. The moisture values were calculated as follow:

$$
H=\left(\frac{V_{\mathrm{H}_{2} \mathrm{O}} \times \rho_{\mathrm{H}_{2} \mathrm{O}}}{w_{\text {sample }}}\right)
$$

where $V_{\mathrm{H}_{2} \mathrm{O}}$ is measured as the aqueous phase volume $(\mathrm{mL}), \rho_{\mathrm{H}_{2} \mathrm{O}}$ is the water density $\left(\mathrm{g} \mathrm{mL}^{-3}\right)$ and $w_{\text {sample }}$ is the sample mass $(\mathrm{g})$.

\subsection{HYDRODISTILLATION}

The hydrodistillation technique was employed to extract the volatile oil from the dried sample using a Clevenger-type apparatus according to the method recommended by Brazilian Pharmacopeia (Farmacopéia, 1999).A total of $30 \mathrm{~g}$ of dried leaves were homogenized and placed in a $1000 \mathrm{~mL}$ round-bottom flask with $500 \mathrm{~mL}$ of distilled water. The preparation was boiled for $180 \mathrm{~min}$ at atmospheric pressure $(93.50 \mathrm{kPa})$. The oil obtained was separated and dried over the minimum amount of anhydrous sodium sulfate to remove traces amount of moisture. The essential oil was stored at $278.15 \mathrm{~K} \pm 2 \mathrm{~K}$ until further analysis.

\subsection{GAS CHROMATOGRAPHY-MASS SPECTROMETRY}

GC-MS analysis was carried out using a gas chromatograph (Agilent@ ${ }^{\circledR} 7890 \mathrm{~A}$ ) coupled to a mass selective detector (Agilent ${ }^{\circledR} 5975 \mathrm{C}$ ) in El mode at $70 \mathrm{eV}$ with a nonpolar 
capillary column VF-5MS (30 m, $0.25 \mathrm{~mm}$ and a film thickness of $0.25 \mu \mathrm{m}, 5 \%$ phenyl-95\% dimethylpolysiloxane). The carrier gas used was helium with injection volume $1.0 \mu \mathrm{L}$. Source and quadrupole temperatures were $503.15 \mathrm{~K}$ and $423.15 \mathrm{~K}$, respectively. The mass spectrometer was programmed to detect the 40.0-1000.0 mass/charge $(\mathrm{m} / \mathrm{z})$ ratio. The initial column temperature was $473.15 \mathrm{~K}$, maintained for 2 minutes, with heating $4 \mathrm{~K} \mathrm{~min}^{-1}$ to 573.15 $\mathrm{K}$, kept for 4 minutes.

The active compound characterization was made by comparing retention time, Kovats retention indice $(\mathrm{KI})$ calculated relative to n-alkanes (Alkane standard solution C8-C40 4070 Fluka) and recorded mass spectra with those stored in the NIST-11 mass spectral library of the GC-MS data system of the apparatus. The other data processing approach used was the AMDIS (Automated Mass Spectral Deconvolution and Identification System) software. For compounds confirmation, literature data were compared to values obtained by Equation 2:

$$
I K_{x}=100 y+100(z-y) \frac{t_{(r) x}-t_{(r) y}}{t_{(r) z}-t_{(r) y}},
$$

where $y$ is the carbon number of the standard to the left of the peak of the evaluated compound, $\mathrm{z}$ is the carbon number of the standard to the right of the peak of the evaluated compound, $t_{(r) x}$ is the retention time of the subject compound $(\mathrm{min}), t_{(r) y}$ is the standard retention time on the left $(\mathrm{min})$, and $\mathrm{t}_{(\mathrm{r}) \mathrm{z}}$ is the retention time of the right standard $(\mathrm{min})$.

\subsection{ANTIOXIDANT ACTIVITY}

\subsubsection{DPPH spectrophotometric assay}

The antioxidant activity was determined following the procedure described by Mensoret al. (2001) using 1.1-Diphenyl-2-picrylhydrazyl (DPPH•) as the reactant. Solutions with final concentrations ranging from 25 to $125 \mu \mathrm{L} \mathrm{mL}^{-1}$ were prepared from an ethanolic stock solution $\left(2.5 \mathrm{~mL} \mathrm{~mL}^{-1}\right)$ of the oil. Aliquots $(2.5 \mathrm{~mL})$ of each oil solution were transferred to test tubes protected against the light, and $1.0 \mathrm{~mL}$ of a freshly prepared ethanolic solution of DPPH $(0.3 \mathrm{mM})$ was added to each tube. This mixture was mixed well and left to react in a dark place for $30 \mathrm{~min}$ at room temperature. The absorbance ( $\mathrm{abs}_{\text {sample }}$ ) was then measured at $517 \mathrm{~nm}$ using a spectrophotometer (Bel Photonics, 2000UV). The blank was prepared by mixing $1.0 \mathrm{~mL}$ of ethanol with $2.5 \mathrm{~mL}$ of each oil solution. The negative control was prepared by mixing $1.0 \mathrm{~mL}$ of $\mathrm{DPPH} \cdot$ solution and $2.5 \mathrm{~mL}$ of ethanol. The absorbance of these solutions was also measured ( $\left(\mathrm{bbs}_{\mathrm{blank}}, \mathrm{abs}_{\mathrm{contro}}\right)$. The tests were carried out in triplicate, and the antioxidant activity (AA) was calculated using Equation 3:

$$
A A(\%)=100-\left\{\frac{\left[\left(a b s_{\text {sample }}-a b s_{\text {blank }}\right) \times 100\right]}{a b s_{\text {control }}}\right\}
$$

The antioxidant activity was also expressed as the half-maximal inhibitory concentration $\left(\mathrm{IC}_{50}\right)$, defined as the concentration $\left(\mu \mathrm{L} \mathrm{mL}^{-1}\right)$ of oil required to inhibit the production of radicals by $50 \%$. 


\subsubsection{Phosphomolybdenum reducing method}

The total antioxidant activity was determined by the spectrophotometric method involving phosphomolybdenum reduction, as described by Prietroet al. (1999). It is based on the reduction of $\mathrm{Mo}^{6+}$ to $\mathrm{Mo}^{5+}$ with subsequent formation of a phosphate- $\mathrm{Mo}^{5+}$ complex, which presents maximum absorption at $695 \mathrm{~nm}$. A $1.0 \mathrm{mg} \mathrm{mL}^{-1}$ aliquot of the solution $(0.01 \mathrm{~g}$ of oil and $10.0 \mathrm{~mL}$ of ethanol) was combined with $1.5 \mathrm{~mL}$ of reagent solution $(0.6 \mathrm{M}$ sulfuric acid, $28.0 \mathrm{mM}$ sodium phosphate, and $4.0 \mathrm{mM}$ ammonium molybdate). The samples were incubated at 368.15 $\mathrm{K}$ for $90 \mathrm{~min}$. After the samples cooled down to room temperature, they were centrifuged, and the absorbance of the solution was measured at $695 \mathrm{~nm}$ against a blank (1.5 mL of reagent solution and $0.02 \mathrm{~mL}$ of ethanol). The analysis was conducted in triplicate. The results were expressed as $\mathrm{mg}$ of $\alpha$-tocopherol $\mathrm{mL}^{-1}$ of oil.

\subsection{ANTIBACTERIAL ACTIVITY}

The antibacterial properties of the oil obtained were tested by the agar well method (Bauer et al.,1996).Two Gram-positive bacterial strains, Staphylococcus aureus (ATCC25923) and Listeria monocytogenes (ATCC19111), and three Gram-negative bacterial strains, Escherichia coli (ATCC25922), Pseudomonas aeruginosa (ATCC27853), Salmonella typhimurium (ATCC14028) were tested.

The selected bacterial strains were inoculated into $10.0 \mathrm{~cm}^{3}$ of trypticase soy broth (TSB) at $308.15 \mathrm{~K}$ for $24 \mathrm{~h}$. Suspensions of bacteria $(50.0 \mu \mathrm{L})$ were prepared and adjusted by comparison according to the McFarland turbidity scale, standard No. 0.5 , and seeded using sterile cotton swabs on trypticase soy agar (TSA) plates. Agar wells were prepared with a sterilized cork borer with a $7.0 \mathrm{~mm}$ diameter. The samples of extracts were dissolved in DMSO (200.0 $\mu \mathrm{L}$ of each sample in $600.0 \mu \mathrm{L}$ of DMSO), and $40.0 \mu \mathrm{L}$ of the solutions were added to different wells in the plates. The plates were kept at room temperature $(295.15 \mathrm{~K})$ for $3 \mathrm{~h}$ to allow diffusion of the solution in the culture medium before the growth of microorganisms and incubated in an upright position at $308.15 \mathrm{~K}$ for $24 \mathrm{~h}$. $50.0 \mu \mathrm{L}$ of DMSO was used as the negative control.. The antibacterial activity was assessed by the formation or not of inhibition zones around the wells. Assays were performed in triplicate, and the diameters of the inhibition zones (in $\mathrm{mm}$ ) were measured.

\section{RESULTS AND DISCUSSION}

\subsection{EXTRACTION YIELD}

The fresh leaves of pitanga presented humidity of $60.00 \pm 1.22 \mathrm{wt} \%$ and were dried until $10.28 \pm 1.05 \mathrm{wt} \%$ of humidity. The dried leaves were used to obtain the essential oil (EO) by hydrodistillation. The yield of pitanga EO was $1.34 \pm 0.18$ wt $\%$ on a dry basis.

\subsection{CHEMICAL COMPOSITION}

The compounds identified by GC-MS analysis of the pitanga leaves essential oil are presented in Table 1. 17 compounds were identified, which represent, on average, 
approximately $55 \%$ of the oil mass. The major compounds identified in the volatile fraction of the oil were germacrone (13.57\%), spathulenol (7.49\%), curzerene (5.31\%), a-cadinol $(4.70 \%)$, shyobunone (4.16\%), $\beta$ and $\gamma$-elemene (6.15\% in total), cis-jasmone $(2.91 \%)$ and cubenol $(2.92 \%)$.

TABLE 1 - CHEMICAL COMPOSITION (\%) OF THE VOLATILE FRACTION OF PITANGA LEAVES OIL OBTAINED BY HYDRODISTILLATION

\begin{tabular}{|c|c|c|c|c|}
\hline Compounds & $\mathrm{Rt}(\min )$ & $\mathrm{RI}^{\mathrm{a}}$ & $\mathrm{RI}^{\mathrm{b}}$ & Relative area (\%) \\
\hline Linalol & 10.78 & 1099 & 1098 & 0.26 \\
\hline p-tertamylphenol & 14.30 & 1224 & 1256 & 0.53 \\
\hline cis-jasmone & 16.65 & 1311 & 1394 & 2.91 \\
\hline$\beta$-elemene & 18.85 & 1396 & 1391 & 3.03 \\
\hline Caryophylene & 19.52 & 1423 & 1428 & 1.48 \\
\hline y-elemene & 19.80 & 1434 & 1433 & 3.12 \\
\hline a-Muurolene & 20.57 & 1465 & 1477 & 1.30 \\
\hline Germacrene-D & 21.07 & 1486 & 1480 & 1.06 \\
\hline curzerene & 21.65 & 1510 & 1506 & 5.31 \\
\hline Shyobunone & 21.97 & 1523 & - & 4.16 \\
\hline (-)- $\beta$-Cadinene & 22.14 & 1531 & 1519 & 1.83 \\
\hline Spathulenol & 22.56 & 1549 & 1576 & 7.49 \\
\hline cubedol & 24.88 & 1650 & 1642 & 2.92 \\
\hline$\alpha$ - Cadinol & 25.29 & 1668 & 1653 & 4.70 \\
\hline Germacrone & 26.30 & 1715 & - & 13.57 \\
\hline Lanceol, cis & 28.11 & 1800 & 1737 & 0.82 \\
\hline Ledene oxide -(II) & 28.75 & 1832 & 1890 & 0.63 \\
\hline TOTAL & & & & 55.12 \\
\hline
\end{tabular}

Rt, retention time.

$\mathrm{RI}$, retention indices

${ }^{\mathrm{a}}$ Calculated retention index.

${ }^{\mathrm{b}}$ Retention index from Pherobase and Leffingwell.

A study by Claesonet al. (1993) showed germacrone has anti-inflammatory activity. Zhong et al. (2011) demonstrated that germacrone present in Curcuma extract inhibited cell proliferation of human breast cancer (anti-tumor activity). Spathulenol is one of the main components in the essential oil of Baccharissemiserrata (Mendes et al., 2008) and Kundmannia species (Paksoyet al., 2016). The latter authors stated that this compound has anticancer, antimicrobial and immunomodulatory effects. It can be applied to foods, medicines, cosmetics, personal care and cleaning products (Mendes et al., 2008, Paksoyet al., 2016).

The chemical composition of Pitanga leaves EO was different from the supercritical extract obtained by Garmuset al. (2014) and the EO characterized by Victoria et al. (2012). They obtained germacrenes and selina-1,3,7-(11)-trien-8-one as the major compounds. On the contrary, the present study obtained germacrene as a minor constituent and selina-1,3,7-(11)trien-8-one was not detected. Similarly, Lagoet al. (2011) did not identify selina-1,3,7(11)-trien8-one in the pitanga leaves EO.Victoria et al. (2013) also found curzerene (4\%) as a major compound.

Previous research (Ogunwandeet al., 2005) detected low amounts of germacrone (2.60\%), and spathulenol (1.50\%) in pitanga leaves EO. Besides, curzerene $(19.70 \%)$ was also a significant compound in the oil.According to Burt (2004), the chemical composition of essential oils from a plant species varies considerably, due to geographical origin and harvesting period. These differences are related to the plant chemotype and extraction method used (Garmuset al., 2014).Feippeet al. (2011) found variability in antioxidant components at the intra-species 
level and among different species of Uruguayan native fruits, such as Pitanga.They suggest that this information could be used for the breeding of commercial cultivars.

\subsection{ANTIOXIDANT ACTIVITY}

The highest antioxidant activity was $64.66 \%$ obtained for oil at a concentration of 125 $\mu \mathrm{L} \mathrm{mL^{-1 }}$, as shown in Figure 1. The antioxidant activity of the pitanga leaves EO was considered high. This result is due to the extraction of polar compounds which have high antioxidant activity (Mensoret al., 2001).

\section{FIGURE 1 - ANTIOXIDANT ACTIVITYOF DPPH AS A FUNCTION OF THE ESSENTIAL OIL CONCENTRATION}

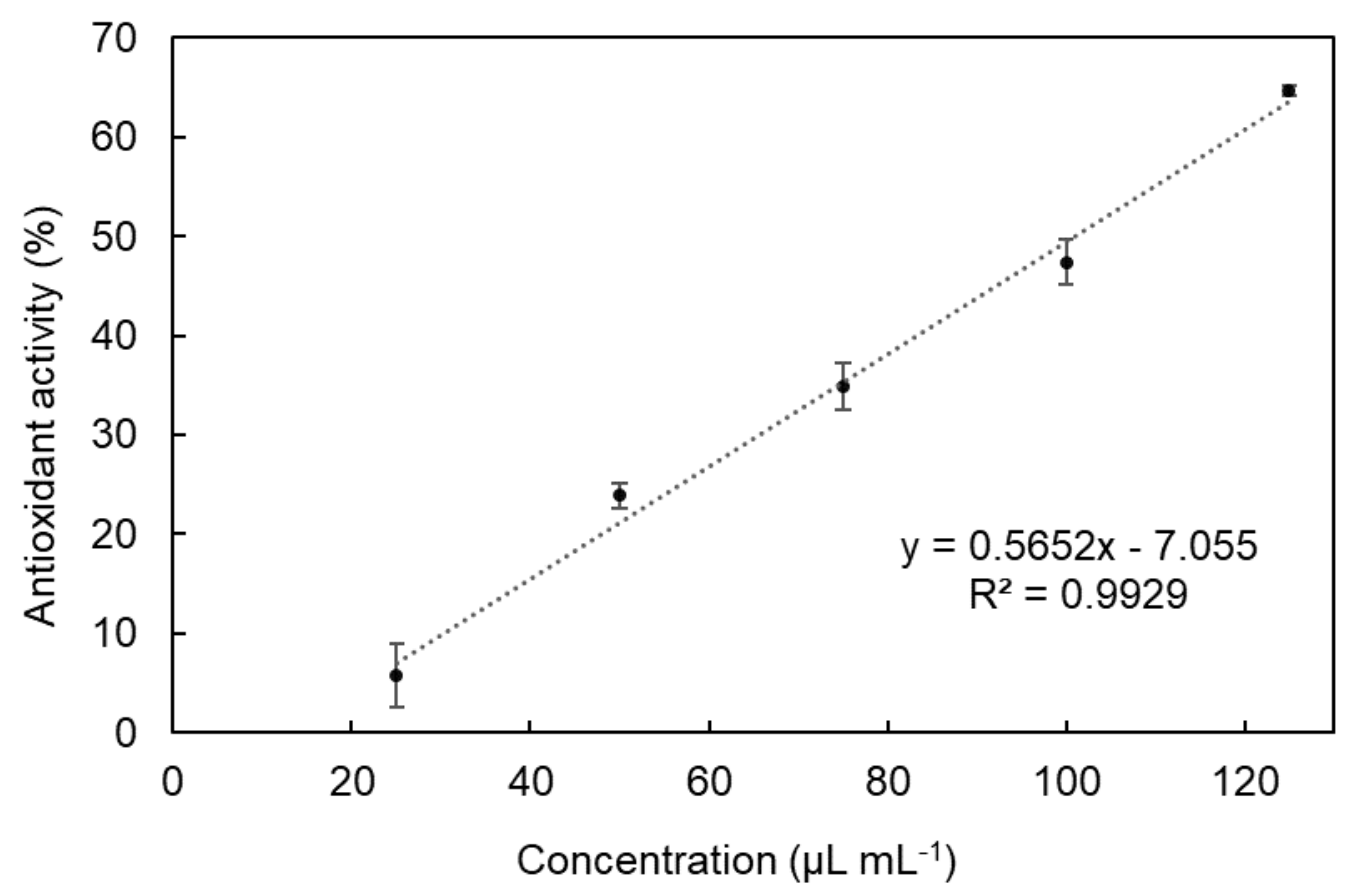

The value of $I C_{50}$ obtained from the linear regression was $100.96 \mu \mathrm{L} \mathrm{ml}^{-1}$ (Figure 1). Studies report that extracts which are considered very active present $\mathrm{IC}_{50}$ value $<50 \mathrm{mg} \mathrm{mL}^{-1}$, the moderately active extracts have $\mathrm{IC}_{50}$ of 50 to $100 \mathrm{mg} \mathrm{mL}^{-1}$, slightly from 100 to $200 \mathrm{mg} \mathrm{mL}^{-1}$ and the ones considered inactive present an $\mathrm{IC}_{50}>200 \mathrm{mg} \mathrm{mL}^{-1}$ (Reynertsonet al., 2005). Consequently, the EO was moderately active.

Additionally, the present EO was considered more active than reported by Victoria et al. (2012) and Victoria et al. (2013). They obtained an $\mathrm{IC}_{50}$ value of $833.3 \mu \mathrm{g} \mathrm{mL}^{-1}$ and 325.0 $\mu \mathrm{g} \mathrm{mL}^{-1}$ for pitanga leaves EO, respectively. On the other hand, Garmuset al. (2014) found $\mathrm{IC}_{50}<50 \mu \mathrm{g} \mathrm{mL}{ }^{-1}$ for most extracts of pitanga leaves using a sequential extraction in fixed bed.

The total antioxidant activity determined by phosphomolybdenum reducing method was of $1503.44 \pm 29.48 \mathrm{mg}$ tocopherol $\mathrm{mL}^{-1}$ of oil. The value was higher when compared to ginger (Zingiberofficinale R.) extracts obtained using compressed propane and $\mathrm{scCO}_{2}$ which

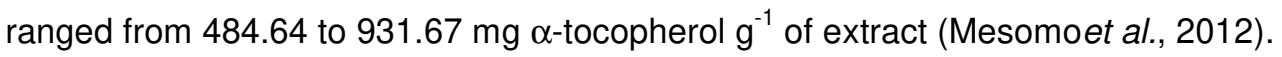


Therefore, the pitanga oil may be applied as an antioxidant in food products. It should be emphasized that the antioxidant compounds detected in each antioxidant method are not necessarily the same onessince the extracts are mixtures of compounds which can have either antagonistic or synergist interactions (Martinez-Correa et al., 2011).

\subsection{ANTIBACTERIAL ACTIVITY}

Table 2 shows the antibacterial activity of pitanga leaves EOagainst the five microorganisms tested.The essential oil showed inhibition only against bacteria of the gender Staphylococcus aureus, with an average diameter of the inhibition zones of $16.8 \pm 2.0 \mathrm{~mm}$. S. aureus is a Gram-positive bacterium which is more sensitive to the antibacterial action of essential oils, compared to Gram-negative bacteria (Nikaido andVaara, 1985, Vaara, 1992). The other Gram-positive bacteria studied, Listeria monocytogenes, and the Gram-negative Escherichia coli, Pseudomonas aeruginosa, Salmonella typhimurium did not form inhibition halos. The negative control with DMSO did not present inhibition, as expected.

\section{TABLE 2 - ANTIBACTERIAL ACTIVITY OF ESSENTIAL OIL OF PITANGA LEAVES AGAINST SELECTED BACTERIAL SPECIES USING AGAR WELL METHOD}

\begin{tabular}{lcc}
\hline & \multicolumn{2}{c}{ Diameter of inhibition zone $(\mathrm{mm})^{\star}$} \\
\hline \multicolumn{1}{c}{ Bacterialspecies } & Pitanga leaves EO & Negative control (DMSO) \\
\hline Staphylococcus aureus & $16.8 \pm 2.0$ & $0.0 \pm 0.0$ \\
Listeriamonocytogenes & $0.0 \pm 0.0$ & $0.0 \pm 0.0$ \\
Escherichia coli & $0.0 \pm 0.0$ & $0.0 \pm 0.0$ \\
Pseudomonasaeruginosa & $0.0 \pm 0.0$ & $0.0 \pm 0.0$ \\
Salmonellatyphimurium & $0.0 \pm 0.0$ & $0.0 \pm 0.0$ \\
\hline
\end{tabular}

*Mean \pm standard deviation of triplicate experiments.

These results agree with Victoria et al. (2012) findings for Pitanga leaf EO. They also did not observe antimicrobial activity against Gram-negative strains. The oil showed the antibacterial potential against $S$. aureus and $L$. monocytogenes.

Ogunwandeet al. (2005) reported that Pitangafruit oil had a stronger inhibition to the growth of $S$. aureus than Pitanga leaf oil. This oil also showed a weak antimicrobial effect against $E$. coli and $P$. aeruginosa. The authors concluded that the leaf oil had the stronger antibacterial effect against Bacillus cereus which was not tested in the present study.

Pereira et al. (2017) demonstrated that Pitanga leaves EO had antibacterial effect against $S$. aureus and E. coli. Similarly, the researchers observed that the oil did not have antimicrobial activity against $P$.aeruginosa. They stated that it was more effective against Grampositive since Gram-negative bacteria is more resistant to the action of natural antimicrobials due to the external membrane which forms a protective envelope.Lago et al. (2011) also concluded that Pitanga leaves EO was active towards two Gram-positive strains, Streptococcus equiand Staphylococcus epidermis. Pitanga leaves essential oils used in the studies may result in antimicrobial activity against different microorganisms due to theirchemical composition (i.e. compounds and quantities found).

Therefore, the application of the EO of pitanga leaves in foods may be interesting to prevent $S$. aureus growth, which is a bacterium that causes staphylococcal food poisoning, a form of gastroenteritis with rapid onset of symptoms. 


\title{
4 CONCLUSIONS
}

The essential oil of pitanga leaves presented high antioxidant activity and contained chemical compounds with proven antioxidant and antimicrobial properties. Additionally, it hadan antimicrobial effect against the pathogenic bacterium Staphylococcus aureus. This oil has the potential to be applied in various products as a natural antioxidant and antimicrobial.

\section{RESUMO}

\section{ATIVIDADE BIOLÓGICA DE ÓLEO ESSENCIAL DE FOLHAS DE PITANGA (Eugenia uniflora L.)}

\begin{abstract}
Muitos extratos naturais apresentam propriedades antioxidantes e antimicrobianas que podem vir a substituir aditivossintéticos. Este estudo teve como objetivo extrair o óleo essencial das folhas de Pitanga (Eugenia uniflora L.) e avaliar sua composição química e atividades antioxidante e antibacteriana. $O$ óleo essencial foi obtido por hidrodestilação com um rendimento de $1,34 \pm 0,18 \%$. A atividade antioxidante total foi avaliada pelos métodos do DPPH eo fosfomolibdênio. O óleo apresentou valor de $\mathrm{IC}_{50}$ de 100,96 $\mu \mathrm{L} \mathrm{mL}^{-1}$ e $1503,44 \pm 29,48 \mathrm{mg}$ de a-tocoferol $\mathrm{mL}^{-1}$ de óleo. Os principais compostos identificados pelo GC-MS foram germacrona (13,57\%),spathulenol (7,49\%), curzereno (5,31\%) e a-cadinol $(4,70 \%)$. O óleo também foi avaliado quanto à sua atividade antimicrobiana e foi efetivo contra Staphylococcus aureus. Estes resultados mostram que o óleo essencial das folhas de pitanga tem boa atividade antioxidante e antimicrobiana, sendo uma fonte alternativa de compostos bioativos.
\end{abstract}

PALAVRAS-CHAVES: PITANGA; ANTIBACTERIANO; ANTIOXIDANTE; HIDRODESTILAÇÃO

\section{ACKNOWLEDGEMENTS}

The authors thank UNICENTRO and FundaçãoAraucária for the financial support and scholarships.

\section{REFERENCES}

1 Alexandre, E. M. C., Castro, L. M. G., Moreira, S. A., Pintado, M., Saraiva, J. A. Comparison of Emerging Technologies to Extract High-Added Value Compounds from Fruit Residues: Pressure- and Electro-Based Technologies. Food Eng. Reviews, 9 (3), 190-212, 2017.

2 AOCS, American Oil Chemists Society. Official methods and recommended practices. Champaign, 1994.

3 Bauer, A. W., Kirby, W.M.M., Sherris, J.C., Turck, M. Antibiotic susceptibility testing by standardized single disc method. Am. J. Clin. Pathol., 45, 493-496, 1996.

4 Bezerra, I.C.F., Ramos, R.T.M., Ferreira, M.R.A., Soares, L.A.L. Chromatographic profiles of extractives from leaves of Eugenia uniflora, Rev. Bras. Farmacogn., 28 (1), 92-101, 2018. 
5 Botterwerck, A. A. M., Verhagen, H., Goldbohm, R. A., Kleinjans, J., Brandt, P. A. Intake of butylated hydroxyanisole and butylated hydroxyl toluene and stomach cancer risk: results from analyses in the Netherlands cohort study. Food Chem. Toxicol., 38, 599-605, 2000.

6 Burt, S. Essential oil: their antibacterial properties and potential applications in foods - a review. Int. J. Food Microbiol., 94, 223-253, 2004.

7 Cavalcanti, R. N., Forster-Carneiro, T., Gomes, M. T. M. S., Rostagno, M. A., Prado, J. M., Mereiles, M. A. A. Uses and Applications of Extracts from Natural Sources. In: Natural Product Extraction: Principles and Applications. The Royal Society of Chemistry, 1-57, 2013.

8 Chan, E. W. C., Lim, Y. Y., Omar, M. Antioxidant and antibacterial activity of leaves of Etlingeraspecies (Zingiberaceae) in Peninsular Malaysia. Food Chem., 104, 1586-1593, 2007.

9 Claeson, P., Panthong, A., Tuchinda, P., Reutrakul, V., Kanjanapothi, D., Taylor, W.C., Santisuk, T. Three non-phenolic diarylheptanoids with anti-inflammatory activity from Curcuma xanthorrhiza. Planta Med., 59, 451-454, 1993.

10 Cunha, F.A.B., Waczuk, E.P., Duarte, A.E., Barros, L.M., Elekofehinti, O.O., Matias, E.F.F., Costa, J.G.M., Sanmi, A.A., Boligon, A.A., Rocha, J.B.T., Souza, D.O., Posser,T., Coutinho, H.D.M., Franco, J.F., Kamden, J.P. Cytotoxicandantioxidativepotentialsof ethanolic extractofEugenia uniflora L. (Myrtaceae) leavesonhumanbloodcells,Biomed. Pharmacother., 84, 614-621, 2016.

11 Denardin, C. C., Hirsch, G. E., Rocha, R. F., Vizzoto, M., Henriques, A. T., Moreira, J. C. F., Guma, F. T. C. R., Emanuelli, T. Antioxidant capacity and bioactive compounds of four Brazilian native fruits. $J$. Food Drug Anal., 23, 387-398, 2015.

12 Farmacopeia Brasileira. Ministério da Saúde - Agencia Nacional da Vigilância Sanitária, 5 Edição, Atheneu Editora, São Paulo, 1999 (in Portuguese).

13 Feippe, A., Ibanez, F., Calistro, P., Zoppolo, R., Vignale, B. Uruguayan native fruits provide antioxidant phytonutrients and potential health benefits. Acta Hort., 918, 443-447, 2011.

14 Franzon, R. C., Carpenedo, S., Viñoly, M. D., Raseira, M. C. B. Pitanga - Eugenia uniflora L. In: Exotic Fruits.Academic Press, 333-338, 2018.

15 Garmus, T. T., Paviani, L. C., Queiroga, C. L., Magalhães, P. M., Cabral, F. A. Extraction of phenolic compounds from pitanga (Eugenia uniflora L.) leaves by sequential extraction in fixed bed extractor using supercritical CO2, ethanol and water as solvents. J. Supercrit. Fluids. Volume 86, Pages 4-14, 2014.

16 Ibañez, E., Kubátová, A., Señoráns, F. J., Cavero, S., Reglero, G., Hawthome, S. B. Subcritical Water Extraction of Antioxidant Compounds from Rosemary Plants. J. Agric. Food Chem., 51, 375, 2003.

17 Kähkönen, M. P., Hopia, A. I., Vuorela, H. J., Rauha J., Pihlaja, K., Kujala, T. S., Heinonen, M. Antioxidant Activity of Plant Extracts Containing Phenolic Compounds. J. Agric. Food Chem., 47 (10), 3954-3962, 1999.

18 Lago, J. H. G., Souza, E. D., Mariane, B., Pascon, R., Vallin, M. A., Martins, R. C. C., Baroli, A., Carvalho, B. A., Soares, M. G., Santos, R. T., Sartorelli, P. Chemical and biological evaluation of essential oils from two species of Myrtaceae-Eugenia uniflora L. and Pliniatrunciflora (O. Berg) Kauser. Molec., 16,9827-9837, 2011.

19 Martinez-Correa, H.A., Magalhães, P.M C.L. Queiroga C.L, Peixoto C.A., Oliveira A.L. Cabral, F.A, Extracts from pitanga (Eugenia uniflora L.) leaves: influence of extraction process on antioxidant properties and yield of phenolic compounds, J. Supercrit Fluids, 55, 998-1006, 2011.

20 Mendes, S., Nunes, D.S. Marques, M.B., Tardivo, R.C., Filho, V.C., Simionatto, E. L., Junior, A.W. Essential oil of BaccharisSemiserrata, a source of Spathulenol. Publ. UEPG Ci. Exatas Terra, 14241245, 2008.

21 Mensor, L.L., Menezes, F.S., Leitão, G.G., Reis, A.S., Dos Santos, T.C., Coube, C.S., Leitão, S.G. Screening of Brazilian Plant Extracts for Antioxidant Activity by the Use of DPPH Free Radical Method. Phytother. Res., 15, 127-130, 2001. 
22 Mesomo, M.C., Scheer, A.P., Perez, E., Ndiaye, P.M., Corazza, M.L. Ginger (Zingiberofficinale R.) extracts obtained using supercritical $\mathrm{CO}_{2}$ and compressed propane: Kinetics and antioxidant activity evaluation. J. Supercrit. Fluids, 71, 102-109, 2012.

23 Mesomo, M.C., Corazza, M.L., Ndiaye, P.M., Santa, O.R.D., Cardozo, L., Scheer, A.P. Supercritical $\mathrm{CO}_{2}$ extracts and essential oil of ginger (Zingiberofficinale R.): Chemical composition and antibacterial activity. J. Supercrit. Fluids, 80, 44-49, 2013.

24 Misharina, T.A., Terenina, M.B., Krikunova, N.I. Antioxidant properties of essential oils. Appl. Biochem. Microbiol., 45 (6), 642-647, 2009.

25 Nahak, G.,Suar, M., Sahu, R. K. Antioxidant potential and nutritional values of vegetables: A Review. Res. J. Med. Plants, 8 (2), 50-81, 2014.

26 Nikaido H., Vaara M., Molecular Basis of Outer Membrane Permeability. Microbiol. Rev., 49, 1-32, 1985.

27 Ogunwande, I.A., Olawore, N.O., Ekundayo, O., Walker, T.M., Schmidt, J.M., Setzer, W.N. Studies on the essential oils composition, antibacterial and cytotoxicity of Eugenia uniflora L. Int. J. Arom., 15, 147-152, 2005.

28 Paksoy, M.Y.,Diraz, E.,Digrak, M.,Tutar, E, Karaman, S. Essential oil composition and antimicrobial activity of two endeic Kundmannia SCOP. species from Turkey. Ind. Crops Prod., 79, 39-46, 2016.

29 Pereira, N. L. F., Aquino, P. E. A., Júnior, J. G. A. S., Cristo, J. S., Filho, M. A. V., Moura, F. F., Ferreira, N. M. N., Silva, M. K. N., Nascimento, E. M., Correia, F. M. A., Cunha, F. A. B., Boligon, A. A., Coutinho, H. D. M., Matias, E. F. F., Guedes, M. I. F. In vitro evaluation of the antibacterial potential and modification of antibiotic activity of the Eugenia uniflora L. essential oil in association with led lights. Microb. Pathog., 110, 512-518, 2017.

30 Pisoschi, A. M., Pop, A., Georgescu, C., Turcus, V., Olah, N. K., Mathe, E. An overview of natural antimicrobials role in food. Europ. J. Med. Chem., 143, 922-935, 2018.

31 Polônio, M. L.,Peres, F. Food additive intake and health effects: public health challenges in Brazil. Cad. SaúdePública, 25 (8), 1653-1666, 2009.

32 Prieto, P., Pineda, M., Aguilar, M. Spectrophotometric quantitation of antioxidant capacity through the formation of a phosphomolybdenum complex: specific application to the determination of vitamin $\mathrm{E}$. Anal. Biochem., 33, 269, 1999.

33 Reynertson, K.A., Basile, M.J., Kennelly, E.J, Antioxidant potential of seven myrtaceous fruits. Ethnobotany Res. Appl., 3, 2005.

34 Sivasothy, Y., Chong, W. K., Hamid, A., Eldeen, I. M.; SULAIMAN, S. F.; AWANG, K. Essential oils of Zingiberofficinalevar. Rubrum Theiladeand their antibacterial activities. FoodChem., 124, 514-517, 2011.

35 Soares, S.E. Ácidos fenólicos como antioxidantes, Rev. Nutr., 15, 71-81, 2002.

36 Vaara, M. Agents that increase the permeability of the outer membrane. Microbiol. Rev., 56, 395-411, 1992.

37 Van Acker, S. A. B. E.; Van Den Berg, D.; Tromp, N. J. L.; Griffioen, D. H.; Van Bennekom, W. P.; Van Der Vijgh, W. J. F.; Bast, A. Structural aspects of antioxidant activity of flavonoids. Free Radic. Biol. Med., 20 (3), 331-342, 1996.

38 Victoria, F. N., Lenardão, E. J., Savegnago, L., Perin, G., Jacob, R. G., Alves, D., Silva, W. P., Motta, A. S., Nascente, P. S. Essential oil of the leaves of Eugenia uniflora L.: Antioxidant and antimicrobial properties. Food Chem. Toxicol., 50 (8), 2668-2674, 2012.

39 Victoria, F. N.,Brahm, A. S.,Savegnago, L., Lenardão, E. J. Involvement of serotoninergic and adrenergic systems on the antidepressant-like effect of $E$. uniflora $L$. leaves essential oil and further analysis of its antioxidant activity. Neurosci. Lett., 544, 105-109, 2013.

40 Zhong, Z.; Chen, X.; Tan W.; Xu Z.; Zhou, K.; Wu T.; Cui L.; Wang, Y. Germacrone inhibits the proliferation of breast cancer cell lines by inducing cell cycle arrest and promoting apoptosis. Eur. J. Pharmacol., 667, 50-55, 2011. 